Réactions dans l'état solide

Colloques Internationaux du Centre National de la Recherche scientifique, 10. Pp. iv +222 . (Paris : Centre National de la Recherche scientifique, 1950.) 1,100 francs.

$\mathrm{D}$ RING recent years there has been a welcome revival of the pre-war practice of holding international colloquia on scientific subjects, and, with the financial assistance of the Rockefeller Foundation, the Centre National de la Recherche scientifique has been particularly active in this direction. Under the auspices of that body one of the colloquia held during 1948 was on reactions in the solid state ; it took place in Paris during October 1-6 and was attended by many distinguished chemists and physicists of various nationalities. These included Profs. G. Borelius and A. J. Hedvall (Sweden), Dr. E. J. W. Verwey (Netherlands) and Drs. P. W. Selwood and K. J. Laidler (United States). From Great Britain there were Dr. G. W. Brindley (Leeds), Prof. N. F. Mott and Prof. W. E. Garner, Drs. T. J. Gray and J. W. Mitchell (Bristol), Dr. R. M. Barrer (London) and Dr. D. M. C. MacEwan (Rotham sted). Belgium, France, Italy, Norway and Switzerland were also represented.

The proceedings of the colloquium have now been published. The volume consists of the text, in French, of the forty-odd papers and notes presented, together with a preface specially written by Profs. G. Chaudrion and J. Bénard, the able organizers of the colloquium, and is a reprint of the January/ February and March/April 1949 issues of the Bulletin de la Société chimique de France. Each paper is provided with a synopsis.

The concluding paper in the volume is by Prof. A. J. Hedvall, who was one of the pioneers in the study of reactions in the solid state and whose book "Reactionsfahigkeit fester Stoffe", published in 1938, is an authoritative work on the subject. In summing up the conclusions of the various other papers, Prof. Hedvall directs particular attention to the results obtained by magnetic methods such as those on the reactions of solids at transformation temperatures. $\mathrm{He}$ cites various examples of present technical applications of the chemistry of the solid state in the glass, ceramic and concrete industries and in powder metallurgy, and describes some of the research problems being undertaken in his own laboratory.

S. W.

Rocky Mountain Naturalists

By Joseph Ewan. Pp. xv $+358+9$ plates. (Denver, Colo. : University of Denver Press, 1950.) 5 dollars.

OSEPH EWAN'S book falls into two parts. The $\int$ first contains biographies of nine leading naturalists of the Rocky Mountain area, and the second a list, set out in dictionary form, of natural history collectors in the area. Among the biographies is one of Edwin James, the first botanist to visit Colorado to make a systematic collection of plants; John Charles Fremont, the general and botanist who stood as a candidate for the presidency; Charles Christopher Parry, the medical man who named so many Colorado mountains; Harry Norton Patterson, the Oquawka printer and botanist who did much collecting in the Gore Range area; Marcus Eugene Jones, the Iowa teacher of Latin who became an explorer and for more than sixty years travelled in search of rare plants ; Edward Le日 Greene, the Episcopalian rector of Georgetown, Colorado, who besides becoming well known as a writer, is also remembered for his tenacity in advocating the "fixity of species" against all Darwinian protagonists; Thomas Conrad Porter, professor of natural history at Lafayette College, who simultaneously acted as pastor of a Reformed Church and translator of Germanic literature; Eugene Penard, the Swiss protozoologist who compared the Rocky Mountain lakes with those of the Alps; and, finally, Prof. Theodore Dru Alison Cockerell, the friend of Alfred Russel Wallace who, though possessing no academic qualifications, came to be recognized as an authority on fish scales and bees.

This remarkable book is well written and should serve as a useful companion to Prof. S. W. Geiser's "Naturalists of the Frontier", with its accounts of distinguished naturalists of Texas and the Southwest.

\section{Fundamentals of Organic Chemistry}

A Brief Course for Students concerned with Biology, Medicine, Agriculture and Industry. By James Bryant Conant and Prof. Albert Harold Blatt. Pp. ix +413. (New York: The Macmillan Company ; London: Macmillan and Co., Ltd., 1950.) 30s. net.

7 HIS book differs from most elementary works on organic chemistry by beginning with alcohol and taking up hydrocarbons in the third chapter. The aliphatic substances are dealt with separately from the aromatic. The biochemical aspect is emphasized, in view of the type of reader contemplated, and the text is modern. Electronic theories are explained and used in the appropriate places. Quite complicated compounds, such as cholesterol, vitamins, porphyrins, and hormones find their place. The scope is not sufficient for degree students, but for medical students and those beginning organic chemistry the book should be attractive and stimulating. Some of the theoretical sections should interest more advanced students.

\section{Atlas of Drawings of Chordate Anatomy}

By Prof. Samuel Eddy. Pp. xi+150. (New York: John Wiley and Sons, Inc.; London : Chapman and Hall, Ltd., 1949.) 28s. net.

THE American professor of zoology who has to deal with very large classes is driven to adopt any device that will save time and eliminate drudgery. To this end Prof. S. Eddy, with the help of Mrs. Louise Bush, has prepared 189 unlabelled drawings illustrating the morphology of the chief chordate types. By using these he claims that the student sees more, gets a general idea beforehand of what he should find in his dissections, and has a more clearly defined visual picture afterwards than his own laboured and often inaccurate drawings would have given him. Many British zoologists would disagree with him, for in Great Britain the hard way is preferred, which compels the student to observe before committing his ideas to paper, and trains his visual memory, so much more difficult to develop than the verbal memory.

The types employed in this work are Amphioxus, Molgula, the Ammocote larva, dogfish shark, a teleost, Necturus, the alligator, tortoise, pigeon and. cat. The outline drawings are on the whole excellent, and are sufficiently generalized to allow of additions and modifications. There are a few errors, as in the alligator skull (90), and the cat (venous system $151 \mathrm{~A}$ ), and it is somewhat confusing to find arteries some. times white and sometimes black. Also, the description of the figures might be correlated better. Perforations allow of the rearrangement of the pages. 